\title{
Food requirements and weight changes of men on Antarctic expeditions
}

\author{
BY N. W. M. ORR \\ National Institute for Medical Research, Division of Human Physiology, \\ Medical Research Council, Hampstead, London, $\mathrm{NW}_{3}$
}

\section{(Received 10 fuly 1964-Accepted 9 September 1964)}

In the comparatively short history of Antarctic exploration the scourges of scurvy and semi-starvation have played as important a part in the success or failure of expeditions as have the hazards of exposure and accident. Studies have recently been made of the mechanisms that might be involved in man's physiological response to polar conditions (Lewis \& Masterton, 1963). These have included routine measurements of body-weight, skinfold thickness and energy balance, which have helped in evaluating the nutritional requirements of men working in polar regions.

On the British North Greenland Expedition (BNGE, 1952-4) Lewis, Masterton \& Rosenbaum ( 1960 ) found an overall increase of $\mathrm{I} \cdot 5 \mathrm{~kg}$ in body-weight during $\mathrm{I}$ year with marked seasonal fluctuation. Estimates of food intake on the same expedition showed that men were eating 3000-4000 kcal/day at the base camp but also showed that an intake of $4800 \mathrm{kcal} / \mathrm{man}$ daily was insufficient to maintain calorie balance in men who were sledging (Masterton, Lewis \& Widdowson, 1957). On the NorwegianBritish-Swedish Expedition (NBSE, 1949-52), Wilson (r960) noticed a similar weight increase of $3 \mathrm{~kg}$ over 2 years, with seasonal variations. Milan \& Rodahl (I96I) studied the calorie balance of International Geophysical Year scientists and US naval personnel working in the Antarctic. They showed differences in daily calorie intake between 3400 and $4900 \mathrm{kcal} / \mathrm{man}$ depending on the time of year and the activity of the men. They also recorded an overall increase in body-weight, and showed that it could be accounted for by a calorie intake in excess of energy expenditure.

It is now generally agreed that seasonal fluctuations in weight and skinfold thickness reflect the activity patterns of men involved in strenuous outdoor activity during the summer but remaining relatively inactive during the winter; this has been confirmed by Goldsmith (1959), who showed no seasonal variation in the men of the advance party of the Commonwealth Transantarctic Expedition who were forced by circumstances to work out-of-doors on restricted rations throughout the polar winter.

It has been noticed on several occasions that men have lost weight during sledging journeys and have rapidly regained it on return to base. Usually it has been assumed that such sudden changes in weight could only be accounted for by changes in fluid balance. Massey (1956) demonstrated a mean weight loss of $5 \mathrm{~kg}$ in nine men after sledge journeys lasting from 30 to 85 days on diets yielding $4100 \mathrm{kcal} / \mathrm{man}$ daily. During the Ist day after returning to base there was an average increase of $1 \cdot 4 \mathrm{~kg}$ with a further increase of $1.4 \mathrm{~kg}$ by the $5^{\text {th }}$ day. Massey found parallel changes in skinfold 
thickness. From these findings he postulated that loss of weight during sledging journeys was due to dehydration and loss of fat. Wilson (I960) observed a loss of weight of $3 \mathrm{~kg}$ during a 40-day sledge journey when $4200 \mathrm{kcal} / \mathrm{man}$ was the daily ration. He considered that a $3 \mathrm{~kg}$ weight loss could be expected for men involved in strenuous physical activity and surmized that sweating, increased respiration and a disinclination to replace fluid losses caused dehydration and a consequent loss of $5 \%$ of body-weight. Norman (I960) showed that men expended about $5055 \mathrm{kcal} / \mathrm{man}$ daily when sledging and also that they increased their fluid intake. He could demonstrate no dramatic change in fluid balance on return to base.

The experiments now described were designed to clarify some of the problems of weight change and calorie balance in Antarctica.

\section{EXPERIMENTAL AND RESULTS}

The experiments were carried out at Hope Bay, a British Antarctic Survey sledging base, situated at the northern tip of Grahamland (lat. $63^{\circ} 24^{\prime} \mathrm{S}$, long. $56^{\circ} 59^{\prime} \mathrm{W}$ ). They covered 2 years, and thirty men were involved altogether.

\section{Subjects}

The mean age of the thirty subjects was 26 years (range 19-38). Nine men were over $183 \mathrm{~cm}(6 \mathrm{ft})$ in height and the mean was $178 \mathrm{~cm}$ : the shortest man was $165 \mathrm{~cm}$ and the tallest was $185 \mathrm{~cm}$. The mean weight of the men was $73.25 \mathrm{~kg}$ with a range of $90 \cdot 75^{-5} 8 \cdot 25 \mathrm{~kg}$. Skinfold thickness ranged between $12.3 \mathrm{~mm}$ and $4.9 \mathrm{~mm}$ with a mean of $8.1 \mathrm{~mm}$.

The relatively low latitude of Hope Bay made it possible to travel throughout the year and all personnel from geologists to diesel-electric mechanics spent an average of $45 \%$ of their time away from base. Men travelled with dog teams in parties of two or three and journeys lasted from 2 weeks to 4 months.

\section{Diet}

The food at base was varied and plentiful. Mostly tinned or dehydrated, it was liberally supplemented with fresh seal and penguin flesh and with frozen beef and mutton.

The sledging diet was standard and uniform. A box weighing $24 \mathrm{~kg}$ contained rations for two men for Io days: there were small variations from year to year. In 1958 this ration supplied $3900 \mathrm{kcal}$ and in $19594 \mathrm{I} 00 \mathrm{kcal} / \mathrm{man}$ daily. Supplementary rations of biscuits, coffee, chocolate and luxury items were carried if the sledge loads and length of the journey allowed.

A number of experimental boxes were prepared by the Medical Research Council each year (Lewis, de Jong \& Harries, 1963$)$. These boxes were heavier $(28 \mathrm{~kg})$ than the routine boxes $(24 \mathrm{~kg})$ but they provided more calories $(5300 \mathrm{kcal} / \mathrm{man}$ daily) and greater variety. Though many of the additions were appreciated, most men, especially if they were travelling hard, found the wide variety and the complexities of modern packaging no improvement on the previous simplicity. 
Water was obtained by melting snow and ice and, with few fuel restrictions, was always abundant. The daily intake of water on sledging journeys ranged between I500 $\mathrm{ml}$ and $4000 \mathrm{ml} / \mathrm{man}$.

\section{Body-weight}

All the men were weighed when they were on base at approximately monthly intervals. They were weighed in pyjama trousers to the nearest $0.25 \mathrm{~kg}$ in the morning after urinating. An average was taken of all the base measurements of each subject: this was called his average base weight and formed a base-line for comparisons. Salter bathroom scales (Windsor pattern) were carried on certain sledge journeys and early morning measurements were made in the tent.

\section{Skinfold thickness}

Measurements of a double layer of skin and subcutaneous tissue were taken with Harpenden springloaded calipers (Edwards, Hammond, Healy, Tanner \& Whitehouse, I955). The men were often in either cold or uncomfortable situations and it was important to choose sites that were accessible as well as reasonably representative. The five sites that were finally used were:
outer arm, between deltoid and elbow;
chest, anterior axillary line $2.5 \mathrm{~cm}$ above the nipple;
abdomen, $2.5 \mathrm{~cm}$ to the side of the umbilicus;
back, over the inferior tip of the scapula;
cheek, full thickness over the opening of Stensen's duct.

All measurements were taken on the left side of the body. Each site was remeasured, and from the mean of all five sites a figure for each man's average base skinfold thickness was calculated in the same way as for the body-weights. Only changes greater than $0.4 \mathrm{~mm}$ were considered to be outside the range of experimental error.

The calipers were also carried on certain sledging journeys and measurements were made at the same time as men were weighed.

\section{Fluid balance}

Fluid intake and urine output were measured during and after certain sledging journeys. Fluid intake was comparatively simple to measure as the sledging rations were all dehydrated. Mugs were calibrated for each member of the party and the amount of melted snow added to food or drinks was recorded to the nearest $10 \mathrm{ml}$. Urine was passed into 21 . calibrated Polythene bottles and a record of the $24 \mathrm{~h}$ sample was kept. Specific gravity of early morning samples of urine was measured as often as possible. No attempt was made to calculate or assess extrarenal fluid loss.

\section{Base measurements}

A comparison of all measurements taken in any one month over 2 years gives an indication of any seasonal variation that might have occurred. The measurements are presented as percentage means for all the men involved (Table I). It will be seen that there was little fluctuation in body-weight during 2 years (range $98-103 \%$ of base 
average) but that very much higher readings ( I 2 and I09\%) were recorded for skinfold thickness in April of both years, with low readings between July and January.

It was possible to follow twenty subjects for I year from the time they arrived on base (Table 2). Again there was little change in body-weight throughout the year but a sharp fall in skinfold thickness after the 2nd month of residence in Antarctica. Most of the subjects had become involved in cargo hauling and sledging activities by this time and the skinfold measurements remained at the lower level for the remainder of the year.

Table r. Comparison of body-weight and skinfold thickness of a total of thirty men measured over 2 years at an Antarctic sledging base

\begin{tabular}{|c|c|c|c|c|c|c|c|c|c|c|c|c|c|c|}
\hline \multirow[b]{2}{*}{ Month } & \multicolumn{9}{|c|}{ I959 } & & & & & \\
\hline & Apr. & May & June & July & Aug. & Sept. & Oct. & Nov. & Dec. & & & & & \\
\hline $\begin{array}{l}\text { No. of subjects } \\
\text { involved }\end{array}$ & I 7 & 12 & I3 & I 7 & 3 & 0 & 0 & 16 & 8 & & & & & \\
\hline $\begin{array}{l}\text { Body-weight } \\
\text { (\% base average) }\end{array}$ & 99 & 100 & IOI & 99 & 99 & - & - & 100 & 98 & & & & & \\
\hline \multirow[t]{2}{*}{$\begin{array}{l}\text { Skinfold thickness } \\
(\% \text { base average) }\end{array}$} & I I & 107 & 101 & 94 & 99 & - & - & 99 & 95 & & & & & \\
\hline & \multicolumn{12}{|c|}{ I960 } & \multicolumn{2}{|c|}{ I 96I } \\
\hline Month & Jan. & Feb. & Mar. & Apr. & May & June & July & Aug. & Sept. & Oct. & Nov. & Dec. & Jan. & Feb. \\
\hline $\begin{array}{l}\text { No. of subjects } \\
\text { involved }\end{array}$ & 10 & I4 & 13 & 6 & Io & IO & 7 & I I & 5 & I I & I I & 8 & 0 & 13 \\
\hline $\begin{array}{l}\text { Body-weight } \\
\text { (\% base average) }\end{array}$ & 99 & 100 & 100 & 100 & 100 & ror & 100 & 99 & 100 & 103 & 102 & Ior & - & 100 \\
\hline $\begin{array}{l}\text { Skinfold thickness } \\
\text { (\% base average) }\end{array}$ & 96 & IOI & 104 & 109 & 99 & 100 & IOI & 99 & - & 97 & 99 & 9 I & - & 95 \\
\hline
\end{tabular}

Table 2. Comparison of body-weight and skinfold thickness of a total of twenty men measured over I year at an Antarctic sledging base

\begin{tabular}{|c|c|c|c|c|c|c|c|c|c|c|c|c|}
\hline $\begin{array}{l}\text { Months of residence } \\
\text { in Antarctica }\end{array}$ & I & 2 & 3 & 4 & 5 & 6 & 7 & 8 & 9 & IO & II & I 2 \\
\hline No. of subjects involved & 20 & 12 & 13 & I I & 7 & 5 & I & 12 & 6 & 4 & 8 & 5 \\
\hline $\begin{array}{l}\text { Body-weight } \\
\text { (\% base average) }\end{array}$ & 100 & xoo & 100 & 100 & & 100 & & & 100 & & & 101 \\
\hline $\begin{array}{l}\text { Skinfold thickness } \\
(\% \text { base average })\end{array}$ & Iro & rog & 100 & 98 & & IOO & & & 97 & & & 96 \\
\hline
\end{tabular}

\section{Measurements after sledging}

Body-weight and skinfold thickness of two parties returning to base from sledging journeys were measured immediately they had arrived and before they had had anything to eat or drink. During the next 4 days they were measured in the mornings. The members of the first party were $5.25 \mathrm{~kg}$ below their base average weights on the evening of their return after 42 days on sledging rations ('Table 3 ). The following morning they had put on $\mathrm{x} \mathrm{kg}$ and by the 3 rd morning $3.5 \mathrm{~kg}$.

Their skinfold thickness measurements were $\mathrm{I} \cdot 0 \mathrm{~mm}$ below their base average and rose steadily on return.

The two men who made up the second party were $3.5 \mathrm{~kg}$ below their base average 
weight after 40 days on sledging rations (Table 4 ). The following morning they had gained $2.25 \mathrm{~kg}$ and by the 2 nd morning they had gained $4.25 \mathrm{~kg}$. The skinfold measurements fluctuated within $0.4 \mathrm{~mm}$ of their base average. The records of these two parties established the fact that men could put on weight surprisingly quickly when they returned from sledging journeys, and in the subsequent experiments the problem was studied in more detail.

Table 3. Changes in weight and skinfold thickness of three men after sledging in the Antarctic on sledging rations

\begin{tabular}{|c|c|c|c|c|c|c|}
\hline \multirow[b]{2}{*}{ Subject } & \multirow[b]{2}{*}{$\begin{array}{c}\text { Base } \\
\text { average }\end{array}$} & \multirow{2}{*}{$\begin{array}{c}\text { Sledging } \\
\text { (42nd } \\
\text { day) }\end{array}$} & \multicolumn{4}{|c|}{ At base } \\
\hline & & & $\begin{array}{l}\text { 43rd } \\
\text { day }\end{array}$ & $\begin{array}{l}\text { 44th } \\
\text { day }\end{array}$ & $\begin{array}{l}45^{\text {th }} \\
\text { day }\end{array}$ & $\begin{array}{l}4^{6 t h} \\
\text { day }\end{array}$ \\
\hline \multicolumn{7}{|c|}{ Body-weight (kg) } \\
\hline $\begin{array}{l}\text { FK } \\
\text { RT } \\
\text { JA }\end{array}$ & $\begin{array}{l}69 \cdot 5 \\
80 \cdot 25 \\
69 \cdot 0\end{array}$ & $\begin{array}{l}63.0 \\
75.5 \\
64.5\end{array}$ & $\begin{array}{l}64 \cdot 0 \\
76 \cdot 5 \\
66 \cdot 0\end{array}$ & $\begin{array}{l}\overrightarrow{78 \cdot 75} \\
68 \cdot 0\end{array}$ & $\begin{array}{l}67 \cdot 5 \\
78 \cdot 5 \\
68 \cdot 0\end{array}$ & $\begin{array}{l}66 \cdot 5 \\
78 \cdot 25 \\
69 \cdot 0\end{array}$ \\
\hline Mean & $73 \cdot 0$ & $67 \cdot 75$ & $68 \cdot 75$ & - & $7 x \cdot 25$ & $7 I \cdot 25$ \\
\hline \multicolumn{7}{|c|}{ Skinfold thickness (mm) } \\
\hline $\begin{array}{l}\text { FK } \\
\text { RT } \\
\text { JA }\end{array}$ & $\begin{array}{r}4 \cdot 9 \\
10 \cdot 2 \\
9 \cdot 2\end{array}$ & $\begin{array}{l}3 \cdot 7 \\
9 \cdot 2 \\
8 \cdot 4\end{array}$ & $\begin{array}{l}3.8 \\
9.7 \\
8 \cdot 6\end{array}$ & $\begin{array}{l}- \\
9 \cdot 7 \\
8 \cdot 8\end{array}$ & $\begin{array}{r}3 \cdot 9 \\
10.2 \\
8 \cdot 7\end{array}$ & $\begin{array}{r}4.0 \\
11 \cdot 5 \\
9.4\end{array}$ \\
\hline Mean & $8 \cdot \mathbf{r}$ & $7 \cdot 1$ & $7 \cdot 4$ & - & $7 \cdot 6$ & $8 \cdot 3$ \\
\hline
\end{tabular}

Table 4. Changes in weight and skinfold thickness of two men after sledging in the Antarctic on sledging rations

\begin{tabular}{|c|c|c|c|c|c|c|}
\hline \multirow[b]{2}{*}{ Subject } & \multirow[b]{2}{*}{$\begin{array}{c}\text { Base } \\
\text { average }\end{array}$} & \multirow{2}{*}{$\begin{array}{c}\text { Sledging } \\
\text { (4oth } \\
\text { day) }\end{array}$} & \multicolumn{4}{|c|}{ At base } \\
\hline & & & $\begin{array}{l}\text { 4rst } \\
\text { day }\end{array}$ & $\begin{array}{l}\text { 42nd } \\
\text { day }\end{array}$ & $\begin{array}{l}43 \mathrm{rd} \\
\text { day }\end{array}$ & $\begin{array}{l}\text { 44th } \\
\text { day }\end{array}$ \\
\hline \multicolumn{7}{|c|}{ Body-weight $(\mathrm{kg})$} \\
\hline $\begin{array}{l}\text { KA } \\
\text { FK } \\
\text { Mean }\end{array}$ & $\begin{array}{l}70.5 \\
69.5 \\
70.0\end{array}$ & $\begin{array}{l}66 \cdot 5 \\
66 \cdot 5 \\
66 \cdot 5\end{array}$ & $\begin{array}{l}69 \cdot 25 \\
68 \cdot 25 \\
68 \cdot 75\end{array}$ & $\begin{array}{l}71 \cdot 25 \\
70 \cdot 25 \\
70 \cdot 75\end{array}$ & $\begin{array}{l}70 \cdot 0 \\
69 \cdot 5 \\
69 \cdot 75\end{array}$ & $\begin{array}{l}71 \cdot 25 \\
71 \cdot 0 \\
71 \cdot 25\end{array}$ \\
\hline \multicolumn{7}{|c|}{ Skinfold thickness (mm) } \\
\hline KA & $5 \cdot 9$ & $6 \cdot 0$ & $5 \cdot 8$ & $6 \cdot I$ & $5^{\cdot 8}$ & $6 \cdot 2$ \\
\hline FK & 4.9 & 4.9 & 4.9 & $4 \cdot 9$ & 4.9 & 4.3 \\
\hline Mean & $5 \cdot 4$ & $5+5$ & 5.4 & $5 \cdot 5$ & $5 * 4$ & $5^{\cdot 8}$ \\
\hline
\end{tabular}

\section{fourney I}

Two men travelled $650 \mathrm{~km}$ in 19 days in the spring (November). They ate the routine ration supplying $3900 \mathrm{kcal} / \mathrm{day}$ for the first $\mathrm{I} 6$ days and then, while still travelling $3^{2} \mathrm{~km} /$ day, they ate as much as they wanted from the ration boxes. During the first 2 days of recuperation their intake rose to over $9000 \mathrm{kcal} /$ day. Fluid intake and urine output were measured daily.

At the end of 16 days on the strict ration the two men were very hungry, and were $2 \cdot 25 \mathrm{~kg}$ below their base average. The Ist day after eating to capacity the men had 
gained $\mathrm{I} \cdot 75 \mathrm{~kg}$; by the 2 nd day they had regained their base average and on the $3^{\text {rd }}$ day there was again a drop of $0.5 \mathrm{~kg}$ (Table 5).

There were only small fluctuations of skinfold thickness, within $0.4 \mathrm{~mm}$, throughout the journey.

Fluid intake ranged between 1810 and $3375 \mathrm{ml} /$ day while the men were travelling and dieting. The mean daily intake of the two men was $2672 \mathrm{ml} / \mathrm{man}$. During the Ist day of unlimited food the fluid intake was $3125 \mathrm{ml} / \mathrm{man}$.

Daily urine output varied between 875 and $2725 \mathrm{ml}$ with a mean of $1647 \mathrm{ml} / \mathrm{man}$ when the men were on a restricted diet. Subsequent urine outputs were, if anything, slightly higher than before.

Urine specific gravity was measured on 6 mornings and averaged 1023 with a range of $1018-1024$.

This journey showed that men travelling hard and eating only the routine daily ration of $3900 \mathrm{kcal}$ lost weight. There was no evidence of dehydration during this time. When food became unlimited the men's daily intake of dry food increased to $9000 \mathrm{kcal}$ with associated increases in body-weight and no significant change in fluid intake.

Table 5. Sledging journey I : mean values for two men when eating to capacity from sledging rations from the $\mathrm{I} 6 \mathrm{th}$ day

\begin{tabular}{|c|c|c|c|c|c|}
\hline & $\begin{array}{c}\text { Base } \\
\text { average }\end{array}$ & $\begin{array}{l}\text { Sledging } \\
\text { (1 } 6 \text { th day) }\end{array}$ & $\begin{array}{l}\text { Sledging } \\
\text { (1 } 7_{\text {th day })}\end{array}$ & $\begin{array}{l}\text { Sledging } \\
\text { (r8th day) }\end{array}$ & $\begin{array}{l}\text { Sledging } \\
\text { (19th day) }\end{array}$ \\
\hline $\begin{array}{l}\text { Body-weight (kg) } \\
\text { Skinfold thickness (mm) }\end{array}$ & $\begin{array}{l}75 \cdot 25 \\
5 \cdot 3\end{array}$ & $\begin{array}{c}73 \cdot 00 \\
4.9\end{array}$ & $\begin{array}{c}74 \cdot 75 \\
4 \cdot 9\end{array}$ & $\begin{array}{r}75 \cdot 5 \\
5 \cdot 0\end{array}$ & $\begin{array}{r}75^{\circ} \circ \\
5^{\circ} \cdot 0\end{array}$ \\
\hline \multicolumn{6}{|c|}{ (Mean of 29) } \\
\hline Fluid intake $(\mathrm{ml})$ & - & 2672 & 3125 & $356_{3}$ & 2932 \\
\hline Urine output (ml) & - & 1647 & 1937 & 1813 & 2025 \\
\hline Difference $(\mathrm{ml})$ & - & I025 & II 88 & I 750 & 907 \\
\hline Urine sp.gr. & - & 1023 & - & - & - \\
\hline \multicolumn{6}{|c|}{ (Mean of 6) } \\
\hline
\end{tabular}

\section{Journey 2}

Two men repeated the conditions of journey $\mathrm{I}$ as nearly as possible in the early winter (May). They travelled $260 \mathrm{~km}$ in I 5 days. During the first 13 days they rationed themselves to routine boxes yielding $4100 \mathrm{kcal} / \mathrm{man}$ daily. Then, while still travelling, they ate as much as they wanted with a daily intake of between 8000 and $9000 \mathrm{kcal} /$ man.

On the $13^{\text {th }}$ day of restricted diet the men were $3.25 \mathrm{~kg}$ below their base average. The following day, with unlimited food intake they had gained $2 \mathrm{~kg}$ and on the next day a further $0.5 \mathrm{~kg}$ (Table 6).

Skinfold thicknesses were $0.5 \mathrm{~mm}$ below the base average on the $13^{\text {th }}$ day and fluctuated within $0 \cdot 1-0.3 \mathrm{~mm}$ after recuperation.

The daily fluid intake while sledging on a restricted diet varied between 2300 and $3500 \mathrm{ml} / \mathrm{man}$ with an average of $2915 \mathrm{ml} / \mathrm{man}$. The fluid intake on the rst day of unlimited food was $2978 \mathrm{ml} / \mathrm{man}$ and on the next day was $2812 \mathrm{ml} / \mathrm{man}$.

Daily urine output varied between $95^{\circ}$ and $3600 \mathrm{ml} / \mathrm{man}$ with an average of $2025 \mathrm{ml} /$ 
man. With unlimited food intake the urine output was $1750 \mathrm{ml} / \mathrm{man}$ on the Ist day and $195^{\circ} \mathrm{ml} / \mathrm{man}$ on the 2 nd day.

Urine specific gravity varied between Io19 and 103I, with a mean of I025. Both men collected early morning specimens subsequently on base and found a mean specific gravity over ro days of 1024.

The findings on this journey confirmed those of the previous journey in showing that men lost weight on sledging journeys when they confined themselves to rations yielding $4100 \mathrm{kcal} / \mathrm{day}$ or less. There was no evidence of dehydration during either journey. The rapid gain in weight when food became unlimited, although the men were still travelling, could be associated with an increase in the amount of food eaten rather than with any very dramatic change in water balance. Skinfold changes showed a drop while men were travelling on a restricted diet but no great change when the diet became unlimited.

Table 6. Sledging journey 2: mean values for two men when eating to capacity from sledging rations from the $\mathrm{I} 3$ th day

$\begin{array}{lcccc} & \begin{array}{c}\text { Base } \\ \text { average }\end{array} & \begin{array}{c}\text { Sledging } \\ \text { (13th day) }\end{array} & \begin{array}{c}\text { Sledging } \\ \text { (I 4th day) }\end{array} & \begin{array}{c}\text { Sledging } \\ \text { (I5th day) }\end{array} \\ \text { Body-weight (kg) } & 80 \cdot 75 & 77 \cdot 50 & 79 \cdot 50 & 80 \cdot 00 \\ \text { Skinfold thickness (mm) } & 8 \cdot 0 & 7 \cdot 5 & 7 \cdot 4 & 7 \cdot 5 \\ & \text { (Mean of } 18) & & & \\ \text { Fluid intake (ml) } & - & 2915 & 2978 & 2812 \\ \text { Urine output (ml) } & - & 2025 & 1750 & 1950 \\ \text { Difference (ml) } & - & 890 & 1228 & 862 \\ \text { Urine sp.gr. } & - & 1025 & 1022 & 1029\end{array}$

\section{fourney 3}

Three men travelled $400 \mathrm{~km}$ in 70 days during a survey journey in late winter and early spring (August-October). The routine ration of $3900 \mathrm{kcal} /$ day was liberally supplemented with extra biscuits, chocolate and pea flour to yield about $5000 \mathrm{kcal} /$ day. As the party broke up and continued to travel at the end of 70 days no base measurements after sledging were possible.

At the end of 70 days on a supplemented sledging diet the mean weight of the three subjects was $0.25 \mathrm{~kg}$ above their base average. Skinfold measurements differed from the base average by between 0.1 and $0.3 \mathrm{~mm}$ (Table 7 ).

Fluid intake varied between 1625 and $3750 \mathrm{ml} /$ day (mean $2532 \mathrm{ml} /$ day) and urine output varied between 875 and $2750 \mathrm{ml} /$ day (mean $1470 \mathrm{ml} /$ day).

The specific gravity of the early morning urine sample varied between IOI I and 1032 (an average of 1023), and fluid balance measurements during this and the previous journeys gave no indication of dehydration during sledging journeys: the men lost virtually no weight after 70 days on a generously supplemented sledging ration.

The experiment showed that it was not necessary for sledgers to lose weight if their ration was adequately supplemented. 
Table 7. Sledging journey 3 : mean values for three men on the 7oth day when eating to capacity from sledging rations

\begin{tabular}{|c|c|c|}
\hline & $\begin{array}{c}\text { Base } \\
\text { average }\end{array}$ & $\begin{array}{c}\text { Sledging } \\
\text { (7oth day) }\end{array}$ \\
\hline Body-weight $(\mathrm{kg})$ & $71 \cdot 25$ & $7 \times 5$ \\
\hline Skinfold thickness (mm) & 5.7 & $5 \cdot 8$ \\
\hline \multicolumn{3}{|c|}{ (Mean of 18 ) } \\
\hline Fluid intake (ml) & 一 & 2532 \\
\hline Urine output (ml) & - & 1470 \\
\hline Difference $(\mathrm{ml})$ & - & 1062 \\
\hline Urine sp.gr. & - & 1023 \\
\hline
\end{tabular}

Journey 4

Three men, with three dog teams, travelled $65^{\circ} \mathrm{km}$ in 19 days in early summer (November). They based their rations on three MRC Mark IV ration boxes (Lewis et al. I963). The addition of a few luxury items, which were carried separately, brought the daily intake over $\mathrm{I} 8$ days to about $5600 \mathrm{kcal} / \mathrm{man}$.

After I 8 days of hard travelling the mean weight of the three men was $84^{\circ} \circ \mathrm{kg}$, identical with their base average.

Skinfold thickness measurements showed a distinct drop in all three subjects, from a mean value of 9 to one of $7.6 \mathrm{~mm}$. The party broke up at the end of the journey so that recuperative base measurements were not taken.

This experiment confirmed the findings of previous workers who have postulated that an adequate sledging diet should supply between 5000 and $5500 \mathrm{kcal} / \mathrm{man}$ daily if it is to maintain body-weight. The fall in skinfold thickness reflected loss of fat associated with strenuous physical exercise.

\section{DISCUSSION}

\section{Body-weight}

Little overall increase was recorded over 2 years. But, unlike most polar explorers, the subjects were involved in comparatively strenuous outdoor activity all the year round and this was reflected in the absence of the seasonal fluctuations which have been reported previously.

Individual variations in body-weight were, however, recorded when men were involved in sledging journeys. Previously these weight changes have been largely attributed to changes in the body's hydration. Measurements of fluid intake and urine output gave no indication that the men were either dehydrated while they were travelling or that they retained more fluid on return to base. Though no doubt there were changes in water balance when there were changes in the composition or the quantity of the rations, these were not large enough to be detected and were certainly not responsible for measurable changes in weight.

Men lost weight when travelling on a diet yielding $3900 \mathrm{kcal} /$ day and lost little or no weight when travelling under similar conditions on a diet yielding $5000-5600 \mathrm{kcal} /$ day. One can only deduce that the main cause of weight loss was a calorie deficit. 
Some other mechanism than calorie imbalance must have been responsible for the sudden increases in weight that were demonstrated when men who had been rationing themselves to the routine sledging diet took unlimited food. On the sledging diet most men were hungry and when they found supplies of unlimited and varied food they ate voraciously. The same voracity has been noticed in released prisoners of war, and in students subjected to experimental semi-starvation. Widdowson (I95I) during her experiments in Wuppertal at the end of the Second World War, reported that prisoners released from Russia were eating daily up to $9 \mathrm{lb}$ of solid food and 3 pints of soup. Murray (1947) reported that men liberated from German prison camps were eating daily up to $8000 \mathrm{kcal}$, and the subjects of the Minnesota experiment (Keys, Brožek, Henschel, Nickelsen \& Taylor, 1950), when they were allowed unlimited food after 6 months of experimental semi-starvation, were eating daily up to I $000 \mathrm{kcal}$.

During the experiments described here, though conditions were by no means so rigorous, the subjects ate daily up to 8000 or $9000 \mathrm{kcal}$ during the first 2 days that food became unlimited. This represented an increase of about $1.25 \mathrm{~kg}$ in the amount of dry food eaten, which, together with the extra fluid needed for its hydration, closely corresponded to the immediate gain in weight.

\section{Skinfold thickness}

It was originally assumed that when men in polar regions increased their bodyweight and became fat it was due to a physiological response of the body to cold. However, detailed measurements of nutritional balance have shown that seasonal fluctuations in body-weight and skinfold thickness are more closely associated with changes in activity than directly with changes in temperature. Furthermore, Norman's ( 1960 ) work on man's 'microclimate' in Antarctica has shown that the polar explorer, when properly clothed, is exposed to remarkably little cold stress.

In the experiments described here, though there was little change in body-weight throughout the year, there was a distinct decrease in skinfold thickness during the first 2 or 3 months of residence in Antarctica. The decrease in skinfold thickness could well have been the result of increased activity, and the maintenance of body-weight could have been the result of muscular development also associated with increased activity.

During sledging journeys there was usually a decrease in skinfold thickness, which again reflected increased activity. At the end of sledge journeys, when the body-weight increased sharply there was no sharp change in the skinfold thickness, which tended to increase slowly and gradually if the subject remained on base. The steady increase in skinfold thickness suggests that fat was being stored when unlimited food made it possible.

\section{Fluid balance}

It has been shown experimentally that under conditions of moderate work man's fluid intake may vary between 2000 and $4500 \mathrm{ml} /$ day (Bard, I94I). McCance, Young \& Black ( $1943-4)$, in experiments on dehydration and controlled rehydration, showed that dehydrated subjects passed between 335 and $864 \mathrm{ml}$ urine/day, with a specific 
gravity of 1.030 and over. With controlled rehydration they showed a very large increase in water consumption and a temporary fall in urine output until rehydration was complete.

During sledging journeys the daily fluid intake varied between 1500 and $4000 \mathrm{ml}$ and the daily urine output between about 850 and $3000 \mathrm{ml}$ and showed none of the signs, in either quantity or concentration, of dehydration. There was certainly no great increase in fluid intake on return to base or when food became unlimited.

\section{Diet}

There is still considerable difference of opinion as to what constitutes the ideal polar diet. Frazier (1945) reporting on physiological work undertaken during the establishment of Little America III stated that appetites were increased by the cold. Johnson \& Kark (1947) compared the diets suitable for troops operating in the tropics and in polar regions and suggested that as much as an additional $2000 \mathrm{kcal} / \mathrm{man}$ daily or more was required by men working in the cold. Webster (I952) has calculated that men exposed to temperatures of $-30^{\circ} \mathrm{F}$ would expend as much as $1000 \mathrm{kcal}$ in warming and humidifying the expired air alone. And yet, more recently Iampietro, Bass \& Buskirk (I957) after conducting cold-chamber experiments in America have stated that there was no evidence that cold stress imposed additional calorie requirements apart from those resulting from increased muscle activity.

Whether their large appetites are the result of climatic changes or of increased activity or of both, it is certain that men on polar expeditions need a large calorie intake if they are to maintain their body-weight. The exact calorie requirement depends on the size of the man and the work in which he is involved, and there has possibly been a tendency in the past to overstandardize diets so that all men, large and small, active and static, have been given the same ration. Though $3000-4000 \mathrm{kcal} /$ day have supplied the needs of men on base, it was found during the trials under discussion that $5500 \mathrm{kcal} /$ day were just sufficient to maintain the body-weights of large men who were travelling hard.

The composition of the ideal diet is also subject to individual variations. With the great emphasis on pemmican during the early days of Antarctic exploration, the diets probably consisted of between 22 and $33 \%$ protein. And though the rations yielded about $5000 \mathrm{kcal} / \mathrm{man}$ daily much of it may have been wasted. McLean (I9I9) said that fat was necessary in an Antarctic diet, and both Butson (1950) and Masterton et al. (1957) have shown that a high-fat diet was well tolerated and absorbed under polar conditions. Mitchell, Glickman, Lambert, Keeton \& Fahnestock (1946) studied the effects of various diets on man's tolerance to cold and showed that foods high in carbohydrate or fat were preferable to high-protein foods. They also showed that small meals at short intervals were more successful than large meals separated by the usual 4-6 h intervals. A number of men, either through force of circumstances or for preference, have existed in the Arctic and in the Antarctic on a diet consisting almost entirely of fat and protein and appear to have thrived (Nansen, I898; Stefansson, I921).

A critical assessment of some of the more successful sledging diets which have been 


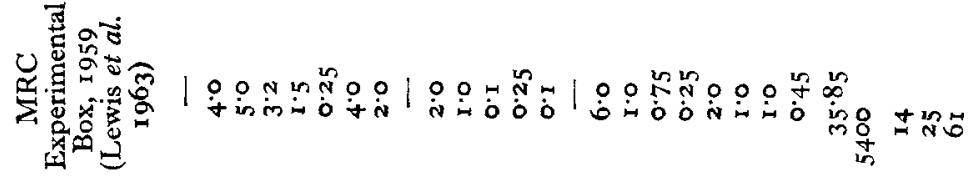

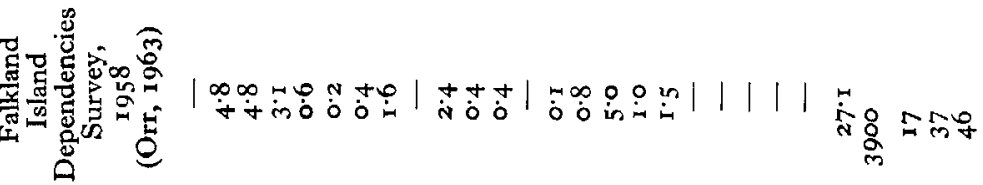

离

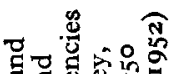

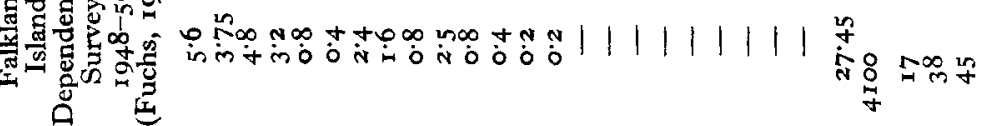

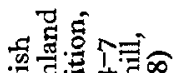

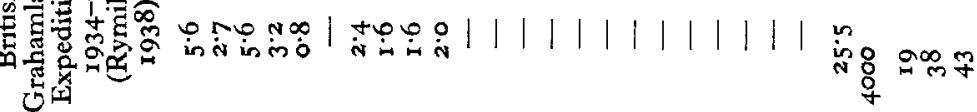

है

占

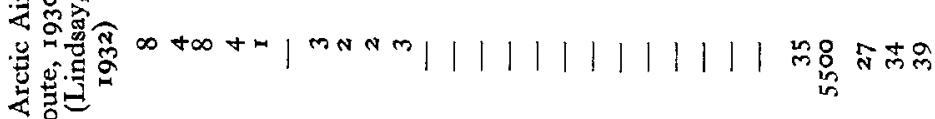

幽

हี

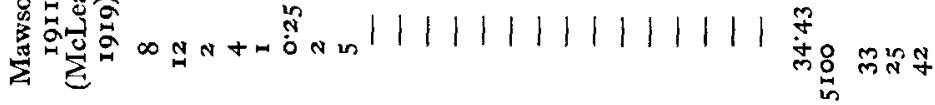

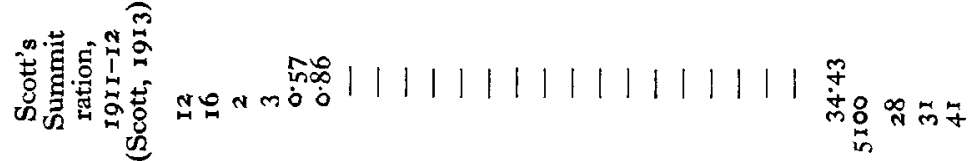

8

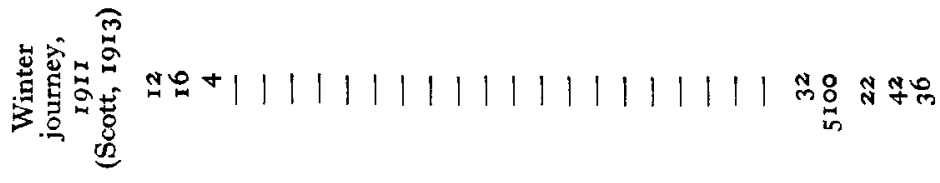

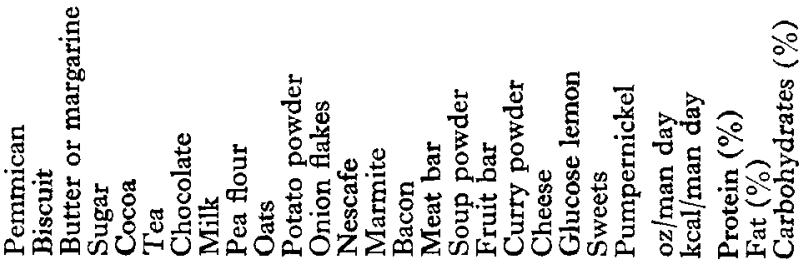


used over the years (Table 8) shows that they have yielded about $5000 \mathrm{kcal} / \mathrm{man}$ daily, of which about $20 \%$ was protein, $40 \%$ was fat and $40 \%$ was carbohydrate. These figures are remarkably similar to those given for the energy requirements during strenuous muscular exercises of Harvard football players, who required $5500 \mathrm{kcal}$ to maintain their body-weight; about $12 \%$ of this requirement was provided by protein, $44 \%$ by carbohydrate and $44 \%$ by fat (Edwards, Thorndike \& Dill, 1935).

If intelligent use is made of the food available on the base and of all the natural resources, vitamin supplements should be unnecessary in Antarctica. Sledging rations have provided little vitamin $\mathrm{C}$ except that in powdered milk. The addition of potato powder and dried onion brings the intake of vitamin $\mathrm{C}$ from the ration used in the experiments described here to just within acceptable limits, and the intake could be augmented by the addition of more milk, or jam or concentrated orange juice.

\section{SUMMARY}

I. Changes in body-weight and skinfold thickness were recorded in thirty men during a period of 2 years at an Antarctic sledging base. There was little overall change in body-weight but marked fluctuations in skinfold thickness. These fluctuations reflected different levels of activity rather than changes in temperature or season.

2. During four sledging journeys changes in body-weight and skinfold thickness were compared with those in calorie intake and fluid balance. The results of these experiments suggested that long-term changes in body-weight reflected a calorie imbalance, whereas sudden changes in body-weight reflected sudden changes in the bulk of the food eaten. There was no evidence of dehydration during sledging journeys and no marked increase in fluid intake on return to base.

3. The calorie intake needed to maintain body-weight varied very widely from man to man and depended on the size of the man and his activity. For most, $5000 \mathrm{kcal} /$ man daily formed an excellent basis for a sledging ration, the composition of which varied again with individuals and with the environment in which they were working.

\section{REFERENCES}

Bard, P. (editor) (1941). Macleod's Physiology in Modern Medicine. London: Henry Kimpton.

Butson, A. R. C. (1950). Lancet, i, 993.

Edwards, D. A. W., Hammond, W. H., Healy, W. T. R., Tanner, J. M. \& Whitehouse, R. H. (1955). Brit. F. Nutr. 9 , I33.

Edwards, H. T., Thorndike, A. \& Dill, D. B. (1935). New Engl. F. Med. 213, 532.

Frazier, R. G. (1945). Proc. Amer. Phil. Soc. 89, 249.

Fuchs, V. E. (1952). Polar Rec. 6, 508.

Goldsmith, R. (1959). Lancet, i, 741.

Iampietro, P. F., Bass, D. E. \& Buskirk, E. R. (I957). Tech. Rep. EP-66 Environmental Protection Research Division, H.Q. Q.M. Research and Engineering Command, Natick, USA.

Johnson, R. E. \& Kark, R. M. (1947). Science, I05, 378.

Keys, A., Brožek, J., Henschel, A., Mickelsen, O. \& Taylor, H. L. (1950). The Biology of Human Starvation. Minneapolis, Minnesota: University of Minnesota Press.

Lewis, H. E., de Jong, A. B. E. \& Harries, J. M. (1963). British Sledging Rations, Recent Developments. Symposium on Antarctic Logistics. Washington, D.C.: National Academy of Sciences, National Research Council.

Lewis, H. E. \& Masterton, J. P. (1963). Lancet, i, roog.

Lewis, H. E., Masterton, J. P. \& Rosenbaum, S. (x960). Clin. Sci. 19, 552. 
Lindsay, M. (r932). Those Greenland Days. London: Blackwood.

McCance, R. A., Young, W. F. \& Black, D. A. K. (1943-4). F. Physiol. x02, 415.

McLean, A. L. (1919). Scientific Reports: Australasian Antarctic Expedition 19r I-1914. Vol. 2. Sidney: A. O. Gullick.

Massey, P. M. O. (I956). Psychology Research Unit, Medical Research Council, A.P.U. 262/56.

Masterton, J. P., Lewis, H. E. \& Widdowson, E. M. (1957). Brit. F. Nutr. 11, 346.

Milan, F. A. \& Rodahl, K. (1961). F. Nutr. 75, I 52.

Mitchell, H. H., Glickman, N., Lambert, E. H., Keeton, R. W. \& Fahnestock, M. K. (1946). Amer. F. Physiol. $x_{46}, 84$.

Murray, R. O. (1947). Lancet, i, 507.

Nansen, F. (1898). Farthest North. London: George. Newnes.

Norman, N. (1960). Man in the Antarctic. M.D. Thesis, University of Glasgow.

Orr, N. W. M. (1963). Food requirements of men and dogs on Antarctic expeditions. M.D. Thesis, University of Cambridge.

Rymill, J. (1938). Southern Lights. London: Chatto and Windus.

Scott, R. F. (I913). Scott's Last Expedition, 2 vols. London: Smith Elder.

Stefansson, V. (1921). The Friendly Arctic. New York: MacMillan.

Webster, A. P. (1952). F. appl. Physiol. 5, 134 .

Widdowson, E. M. (1951). Spec. Rep. Ser. med. Res. Coun., Lond., no. 275, p. 3 I 3.

Wilson, O. (1960). Brit. F. Nutr. 14,391. 